УДК 340

DOI https://doi.org/10.32837/apdp.v0i87.2794

\title{
А.І.Бондаренко
}

\section{РОЛЬ ВЕРХОВЕНСТВА ПРАВА У ПРАВОЗАХИСНІЙ ДІЯЛЬНОСТІ СУЧАСНӦ̈ ДЕРЖАВИ}

Центром дослідницького інтересу стане проблематика державного правозахисту як елемента доктрини верховенства права, яка сьогодні переживає свій ренесанс. Чи можливий державний правозахист за умов відсутності верховенства права? Чи обов'язково верховенство права передбачає повагу й захист прав людини? Наскільки тісно пов'язаними є концепти соціальної справедливості, людських прав і верховенства права в контексті розвитку сучасних моделей соціальної держави, які поступово відходять від класичного розуміння цього поняття? Усі ці питання потребують відповіді для повного і всебічного осмислення проблематики правозахисної діяльності держави як однієї із центральних складових частин соціального прогресу.

Перед аналізом співвідношення державного правозахисту, верховенства права і соціальної справедливості варто розглянути питання про співвідношення верховенства права і прав людини. Хоч у вітчизняній юриспруденції досить поширена думка про те, що верховенство права імпліцитно й апріорно передбачає певний стандарт прав людини $[1 ; 2 ; 3 ; 4 ; 5]$, взаємодія цих двох фундаментально важливих для політичної і правової філософії ідей є не такою однозначною.

У теорії верховенства права відомим є протистояння двох основних підходів: вузького і широкого, або ж «слабкого» і «сильного», або ж формального й субстантивного. Відповідно до вузького (слабкий, формальний) підходу, верховенство права і права людини є незалежними один від одного концептами, між якими не існує жодних зв'язків і взаємозумовленості. Мабуть, найбільш вичерпно і майстерно формальний підхід до верховенства права виклав Дж. Раз у своєму есе «Верховенство права та його чеснота» [6]. Дж. Раз відкидає будь-яку моральну або гуманістичну нормативну наповненість верховенства права, зосереджує увагу на тому, що верховенство права є передусім якістю певної правової системи. Право може існувати і за умов відсутності верховенства права, однак воно водночас буде малоефективним, ненадійним і не надто авторитетним. У цьому контексті він пропонує відому метафору, яка підкріплює його тезу про морально-гуманістичну нейтральність права, отже, і верховенства права. Ніж є інструментом, який використовується для різних цілей: ним можна різати овочі, а можна вбити людину. Одна із принципових якостей ножа, яка робить його гарним, або ж добрим, ножем, - це його гострота. Гострий ніж - це гарний, добрий ніж. Але він є добрим і гарним безвідносно до жодної морально-гуманістичної парадигми, а тому має мало спільного $з$ добром як таким. Гарним, добрим ножем можна так само різати овочі, а можна й убивати людей. Право також є інструментом, хоча й більш специфічним. Право, як сформулював свого часу Лон Фуллер, є особливою соціальною справою, 
процесом підкорення поведінки людей зводу правил [7, с. 11]. Як і в ножа, у права як інструмента є якості, які дають нам змогу визнати його добрим, або ж гарним, правом. Ці якості, як і гострота ножа, можуть не мати нічого спільного з моральними ідеалами. Такими якостями права є те, що правила мають бути стабільними, зрозумілими й відкритими, що закони мають створюватися відповідно до прозорої процедури, що суди мають бути легкодоступними й незалежними, що правозастосовний розсуд не повинен бути настільки широким, щоби створювалася можливість перекручування змісту законів тощо.

Інший популярний варіант концептуалізації верховенства права з погляду формального підходу запропонував Ф.А. Гайєк. Для нього верховенство права означає, що «уряд мусить виконувати правила, встановлені і проголошені заздалегідь, правила, що дають змогу з певністю передбачати, як влада використовуватиме свої повноваження зі здійснення примусу за певних обставин, і планувати власні справи на підставі цього знання» [8, с. 91]. Тут акцентується: верховенство права є радше станом передбачуваності й стабільності, аніж певною інструментальною характеристикою права. Австрійський економіст так само не пропонує субстантивної взаємозумовленості верховенства права і прав людини, робить наголос саме на формальному боці правил, а не на їхньому змісті.

Широке розуміння верховенства права неодмінно передбачає зв'язок між правами людини і правовою нормативністю, причому цей зв'язок не вичерпується зводом формальних вимог щодо того, якими мають бути закони. Цей зв'язок є більш глибоким і передбачає онтологічну взаємозумовленість і переплетеність цих концептів. Як уважає П.М. Рабінович, верховенство права постає як особливий феномен, як «взаємозумовлене існування та взаємоузгоджена реалізація основоположних прав і обов'язків (тобто природних соціальних - точніше, соціально-природних - можливостей і необхідностей) людини, а також людських спільнот, об’єднань й усього суспільства» [5, с. 6-7]. Схожої, хоча й базованої на відмінних методологічних позиціях, думки дотримується також М.І. Козюбра, коли твердить, що «права людини і верховенство права є нероздільними, це явища однієї сутності» [2, с. 69]. Це, на його погляд, зумовлює фундаментальне призначення верховенства права: слугувати містком між управлінсько-адміністративною сферою, де панує державний механізм, і гуманістичною сферою, зорієнтованою на права людини. Саме тому спрямованість діяльності органів влади та їх посадових осіб на забезпечення фундаментальних, невідчужуваних прав людини розглядається сучасною правовою теорією і судовою практикою, зокрема Європейським судом з прав людини та конституційними судами багатьох європейських країн, як безпосередній прояв реалізації верховенства права. В іншій своїй публікації M.I. Козюбра підкреслює, що «першою вимогою до утвердження в суспільстві верховенства права є те, що природні, невід’ємні і невідчужувані права і свободи людини набувають вирішального значення у відносинах між нею і державною владою» [9, с. 4].

Дотримання прав людини визнається вимогою верховенства права також і Венеціанською комісією, яка, утім, пропонує стриманіший підхід до співвідношення цих понять і констатує, що "дотримання верховенства права і дотримання прав людини не обов'язково є синонімами. Проте великою мірою обидві концепції збіга- 
ються між собою» [10, с. 15]. Справді, не всі права людини можуть бути виражені через верховенство права і навпаки. В.В. Лемак у результаті проведення аналізу зв'язку каталогу людських правіздоктриноюверховенстваправа такожпідкреслює, що верховенство права не може мати своєю вимогою захист усіх без винятку прав.

У теорії верховенства права статус прав людини як елемента чи вимоги верховенства права є досить дискусійним. Однак навіть якщо вважати, що верховенство права таки потребує втілення міжнародних стандартів прав людини в національному законодавстві й реальної практики їх поваги та захисту, постає питання, які саме права становлять мінімум такого зобов'язання? Чи повинна правозахисна функція сучасної держави бути орієнтованою на реалізацію всього пакета прав, які сьогодні визнаються міжнародною спільнотою? I чи можливо це за умов разючої соціально-економічної нерівності між державами? А особливо - чи можливо це з урахуванням різних політичних орієнтацій урядів сучасних держав? Наприклад, США відомі своїм неоднозначним ставленням до права на охорону здоров'я. По суті, за американським законодавством охорона здоров'я не є правом, вона є радше привілеєм, який купується за вельми великі гроші (ціна на медичну страховку у США є найвищою у світі). Це пов'язано передусім із політичними нюансами й протистоянням двох ключових американських партій, а також специфікою політичної традиції цієї країни, де охорона здоров'я завжди розумілася як дещо радикально «ліве» .

Зауважимо, що Європейський суд з прав людини традиційно є більш обережним у справі визнання тих чи інших прав такими, які потрібно поважати й імплементувати незалежно від культурних відмінностей. У цьому сенсі справа “Oliari and others v. Italy” [11] є показною, бо в ній Суд уперше визнав неможливість офіційного оформлення одностатевих стосунків порушенням прав людини.

Можна виділити три форми правозахисту, скеровані на соціальну сферу. Перша форма - мінімальна, яка сумірна з найменшим колом державного правозахисту, - це так звана позитивна держава, де соціальне забезпечення базується на індивідуалізмі та захисті корпоративних інтересів. Соціальна політика тут є лише засобом контролю, «амортизатором» соціальних конфліктів, а на соціальні потреби виділяється досить незначна частка коштів державного бюджету. 3 юридичного погляду ця модель характеризується відсутністю розвинутої системи соціального законодавства, натомість діють численні програми соціальної підтримки населення, до яких постійно вносяться поточні коригування. По суті, така форма соціальної держави не передбачає активного правозахисту в соціальній сфері, а лише мінімальну участь державного механізму в гарантуванні й забезпеченні соціальних прав. Однак така модель є достатньою з того погляду, що вона передбачає егалітаристський підхід до проблем соціальної рівності, і тому держава, хай навіть побіжно й несистемно, але долучається до соціального процесу соціального вирівнювання. Це дає змогу, з одного боку, дотримуватися міжнародних зобов'язань у сфері прав людини, з іншого - лишатися в ідеологічному полі верховенства права, базованому на ідеях рівності й індивідуальної автономії. Найбільш показовою країною, яка використовує таку модель соціального правозахисту, є США [12, с. 36-36]. 
Однак сфера державного правозахисту в соціальній галузі може бути суттєво розширена. Інше концентричне коло, яке визначає активність держави у правозахисті, - це «держава соціальної безпеки», що проводить політику повної зайнятості, забезпечує всім громадянам гарантований мінімальний рівень життя і рівність шансів, але не матеріальну рівність (Франція, Великобританія, Іспанія) [13, с. 425]. Така модель визначається більш активним правозахистом у соціальній сфері. По суті, правозахист тут пов'язаний не лише з безпосереднім захистом прав, але й зі створенням соціально-економічних передумов їх непорушення. Соціальні й економічні права можуть гарантуватися тоді, коли для цього створено належні передумови, і вони не можуть вичерпуватися лише формальною рівністю й індивідуальною автономією, як того вимагає верховенство права. Тобто в рамках цієї моделі держава вже певною мірою виходить за межі базових вимог верховенства права.

Нарешті, третя, найширша модель - «держава загального добробуту», у якій забезпечуються рівність, кооперація і солідарність усіх членів суспільства. Соціальна політика щодо всіх без винятку є однаковою. Характерними рисами такої моделі є зменшення різниці в заробітній платі, повна зайнятість, забезпечення трудящим панівного становища в політиці (скандинавські країни) [14]. Тут правозахист деякою мірою збігається із соціальною політикою як такою, і є немислимим без неї.

Отже, зв’язок проблем верховенства права, соціальної справедливості та прав людини зумовлює необхідність побудови інтегральної моделі правозахисної функції сучасної держави, моделі, яка досить адаптивна для того, щоби бути доступною для держав із відмінним рівнем економічного розвитку і водночас такою, що передбачає активний державний правозахист. Цей правозахист не може обмежуватися політичними і громадянськими правами, на чому традиційно акцентується увага в рамках доктрини мінімальної держави, а неодмінно має охоплювати і соціальні права, бо вони, як і громадянські й політичні права, можуть визначати сучасне розуміння верховенства права як егалітаристської ідеології, пов’язаної з людською гідністю. Соціальна справедливість сьогодні стає рушійним чинником відновлення ідеї соціальної держави, переосмислення їі засад з погляду верховенства права і системи прав людини. У цьому сенсі майбутнє соціальної держави полягатиме у створенні інтегральної системи державного правозахисту, у рамках якої різниця між негативними і позитивними правами як предметом правозахисної функції буде несуттєвою.

\section{Jimepamypa}

1. Горбань B.I. Проблема взаємозв'язків верховенства права з демократією і правами людини. Збірник наукових пращь Харківського національного педагогічного університету імені Г.С. Сковороди. Серія «Право». 2017. Вип. 26. С. 118-138.

2. Козюбра М.I. Верховенство права, права людини і місцеве самоврядування: проблеми взаємозв'язків. Наукові записки Національного університету «Києво-Могилянська академія». Серія «Юридичні науки». 2017. Т. 200. С. 67-71.

3. Колодій А.М. Демократія, верховенство права та права людини у контексті європейської інтеграції України. Юридичний вісник. Серія «Повітряне і космічне право». 2008. № 2. С. 33-38.

4. Лемак В.В. Соціально-економічні права людини в контексті верховенства права: вітчизняний досвід закріплення та застосування. Вісник Академї̈ правових наук України. 2010. № 1. С. 40-48. 
5. Рабінович П.М., Луців О.М. Верховенство права : сучасні вітчизняні підходи до інтерпретації. Вісник Академї̈ правових наук України. 2012. № 2. С. 3-16.

6. Raz J. Rule of Law and Its Virtue. Authority of Law : Essays on Law and Morality. 2nd ed. New York : Oxford University Press, 2009. P. 210-230.

7. Фуллер Л.Л. Анатомія права. Київ : Сфера, 1999. 144 с.

8. Хайек Ф. А. Право, законодательство и свобода. Москва : ИРИСЭН, 2006. 644 с.

9. Козюбра М.І. Принцип верховенства права і правової держави: єдність основних вимог. Наукові записки Національного університету «Києво-Могилянська академія». Серія «Юридичні науки». 2007. Т. 64 . С. $3-9$.

10. Верховенство права : доповідь, схвалена Венеційською комісією на 86 му пленарному засіданні, Венеція, 25-26 березня 2011 p. URL: http://www.scourt.gov.ua/clients/vsu/vsu.nsf/6b6c1e2e6ad 3e2fcc225745c0034f4cc/229b826c8ac787dec2257d87004987c3/\$FILE/CDL-AD(2011)003rev-ukr.pdf (дата звернення: 10.04.2017).

11. Oliari and others v. Italy (Applications № № 18766/11 and 36030/11). URL: https://hudoc.echr. coe.int/eng\#\{«itemid":["001-156265"]\}.

12. Овсієнко О.В. Розбудова соціальної держави в Україні: пошук оптимальної економічної моделі. Вісник Національного університету «Юридична академія України імені Ярослава Мудрого». Серія «Економічна теорія та право». 2013. № 3. С. 34-46.

13. Намчук В.А. Розвиток соціальної держави в країнах ЄС. Актуальні проблеми державного управління. 2011. № 2. С. 423-430.

14. Богданов В.С. Ідея справедливості в соціальній політиці сучасної демократичної держави: політико-правовий вимір. Актуальні проблеми держави і права. 2011. Вип. 58. С. 30-37.

\section{Анотація}

Бондаренко А. I. Роль верховенства права у правозахисній діяльності сучасної держави. - Стаття.

Соціальна справедливість субстантивно пов'язана з верховенством права і правами людини, а тому вона має розглядатися у площині державного правозахисту. Зв'язок цих трьох концептів, а також встановлена нами закономірність, що принаймні деякі допущення соціальної несправедливості в державі можуть вести до порушення прав людини й відхилення від верховенства права, створюють підгрунтя для характеристики однієї з тенденцій реалізації правозахисної функції сучасними державами. Ідеться передусім про ренесанс ідеї соціальної держави, яка була проголошена мертвою й утопічною на початку світової фінансової кризи 2008 року. Зараз, після десяти років відновлення, ідеї соціальної державності знову починають набувати концептуальних обрисів і все частіше потрапляють у фокус стратегічного планування правозахисної функції держави. У зв’язку із цим важливо простежити, як змінилося сучасне уявлення про соціальну державність в останніх дослідженнях у царині верховенства права і прав людини.

Розширення концентричної системи державного правозахисту є закономірністю нашого часу, яка пов'язана насамперед з адаптацією глобальної політичної програми сталого розвитку. Ідеологія сталого розвитку передбачає поступове розширення меж соціального державного правозахисту, щоб гарантувати прийдешнім поколінням більш справедливе й рівноправне майбутнє. Права людини безпосередньо пов'язані з доктриною верховенства права, що, своєю чергою, породжує зв'язок між ними і соціальною справедливістю. Суперечливість проблеми належності соціальної справедливості до вимог верховенства права вирішується шляхом запровадження концентричної моделі соціальної держави, у рамках якої розрізняють три межові форми соціальної справедливості, визначені через права людини. Перша форма - мінімальна, яка збігається з найменшим колом державного правозахисту, - це так звана позитивна держава, де соціальне забезпечення базується на індивідуалізмі та захисті корпоративних інтересів. Інше концентричне коло, яке визначає активність держави у правозахисті, - це «держава соціальної безпеки», що проводить політику повної зайнятості, забезпечує всім громадянам гарантований мінімальний рівень життя і рівність шансів, але не матеріальну рівність. Третя, найширша форма - «держава загального добробуту», у якій забезпечуються рівність, кооперація і солідарність усіх членів суспільства.

Ключові слова: права людини, форми правозахисту, соціальна справедливість, позитивна держава, рівність. 


\section{Summary}

Bondarenko $A$. $I$. The role of the rule of law in the human rights activities of the modern state. Article.

Social justice is substantively linked to the rule of law and human rights, and should therefore be seen in the field of state human rights. The connection of these three concepts, as well as the regularity established by us that at least some assumptions of social injustice in the state can lead to human rights violations and deviations from the rule of law, create a basis for characterizing one of the tendencies of modern states. It is primarily a renaissance of the idea of the welfare state, which was declared dead and utopian at the beginning of the global financial crisis in 2008. Now, after ten years of recovery, the idea of social statehood is beginning to take on conceptual shape and increasingly become the focus of strategic planning. In this regard, it is important to see how the current view of social statehood has changed in recent research on the rule of law and human rights.

The expansion of the concentric system of state human rights is a regularity of our time, which is primarily related to the adaptation of the global political program of sustainable development. In general, the ideology of sustainable development envisages the gradual expansion of the boundaries of social state human rights protection in order to guarantee future generations a more just and equal future. Human rights are directly linked to the doctrine of the rule of law, which in turn creates a link between them and social justice. The contradiction of the problem of belonging of social justice to the requirements of the rule of law is resolved by introducing a concentric model of the welfare state, which distinguishes three boundary forms of social justice, defined through human rights. The first form - the minimum, which coincides with the smallest circle of state human rights - is the so-called positive state, where social security is based on individualism and protection of corporate interests. Another concentric circle that determines the activity of the state in human rights is the "state of social security", which pursues a policy of full employment, provides all citizens with a guaranteed minimum standard of living and equal opportunities, but not material equality. The third, broadest form is the "welfare state", which ensures equality, cooperation and solidarity of all members of society.

Key words: human rights, forms of human rights protection, social justice, positive state, equality. 